\title{
Consequences of the choice of an energy system on the results of least-cost formulation of diets for growing-finishing pigs
}

\author{
C. BRETTE *, G. DUQUENNE **, Y. HENRY ***, L. JACQUOT **, \\ M. PALISSE-ROUSSEL **, J.M. PEREZ ***, D. SAUVANT *, \\ Véronique THEILLAUD ** \\ *I.N.A., Paris-Grignon, Département des Sciences Animales, \\ 16, rue Claude-Bernard, 75231 Paris Cedex 05 \\ $*$ Société Sanders, 17, quai de l'Industrie, 91200 Athis-Mons \\ *** I.N.R.A., Station de Recherches Porcines, Saint-Gilles, 35590 L'Hermitage
}

The economic consequences of the energy system used for the expression of the energy value of feedstuffs have not yet been well established. The present work shows how the energy system affects the results of the formulation.

Five methods of expression of feed energy were compared :

- the Digestible Energy content (DE) according to I.N.R.A. tables; (1983) ;

- the Metabolizable Energy (ME) content corrected according to Henry \& Perez

- the Net Energy content for fattening, calculated using the equation proposed by the scientists of Rostock and the digestibility coefficients of the Dutch tables (VEevoderTABEL, 1977) ; 1982);

- the Net Energy content for growth, calculated with the equation of JUST (1975,

- the Net Energy content for growth according to Just, calculated using the digestibility coefficients of the Dutch tables.

A total of 90 blends were formulated by linear programming to appreciate the results taking into account several price situations and the energy density of the diets used. For each method of expression of energy', the passage from one level of energy density to another was made referring to a feed mixture with a determined ingredient composition.

The results were presented so as to emphasize the effect of the explanatory factors (method of expression of energy, price situation and energy density) on the diet composition and cost, shadow prices of non utilized feedstuffs and marginal costs of formulation constraints.

It should be mentionned that :

- the Dutch system is different from the other systems with medium and high energy densities as it tends to advantage mixtures with a diversified composition, with high fat and low cereal and soyabean meal contents;

- the choice of an energy system results in feed substitutions which not only affect a couple of feedstuffs, but at least five groups of feedstuffs : among which cereals, their substitution products, soyabean meal, metropolitan protein sources and fat. The interpretations are therefore difficult and closely dependent on the hypotheses formulated;

- since the energy system modifies the relative competition between the different feedstuffs, it has an economic influence whatever the criterion used : cost price of formulas or diet composition.

Experiments should be made to test the effect on the animal performance of the differences observed between energy systems. 